Ю. В. Вороненко

ORCID https://orcid.org/0000-0003-4945-1817

О. П. Гульчій

ORCID https://orcid.org/0000-0001-8283-8672

К. В. Балашов

ORCID https://orcid.org/0000-0002-7820-4527

Н. М. Захарова

ORCID https://orcid.org/0000-0002-6530-6217

С. М. Туряниця

ORCID https://orcid.org/0000-0002-4294-198X

Ю. М. Мандрик

ORCID https://orcid.org/0000-0001-8949-3355

Національний університет охорони здоров'я України імені П. Л. Шупика

\title{
ДЕТЕРМІНАНТИ ВИБОРУ ФОРМИ БЕЗПЕРЕРВНОГО ПРОФЕСІЙНОГО РОЗВИТКУ: АНАЛІЗ ВІДПОВІДЕЙ ЛІКАРІВ
}

\author{
Yu. V. Voronenko, O. P. Hulchiy, K. V. Balashov, \\ N. M. Zakharova, S. M. Turianytsia, Yu. M. Mandryk \\ Shupyk National Healthcare University of Ukraine

\section{DETERMINANTS OF CHOICE OF CONTINUING PROFESSIONAL} \\ DEVELOPMENT PLAN: ANALYSIS OF PHYSICIANS’ PERSPECTIVES
}

\begin{abstract}
Анотація. Трансформації системи вищої та післядипломної освіти в Україні спонукають навчальні заклади оновлювати підходи до просування свого освітнього продукту. У попередніх дослідженнях були встановлені цільові показники тривалості та формату навчання, дана загальна оцінка важливості чинників вибору форми БПР; встановлені особливості груп користувачів, готових та не готових оплачувати навчання самостійно; визначені ключові фактори вибору форми БПР та здійснена сегментація користувачів. На новому етапі дослідження лікарям було запропоновано оцінити додаткові чинники, які впливають на вибір форми БПР.

Визначені нові чинники вибору навчального циклу: сучасна тематика курсу (14,2 \% опитаних), можливість удосконалення практичних навичок (8,6 \%), тривалість навчання (4,1%), зручне оформлення матеріалів $(4,1 \%)$ тощо. Встановлені статистично вірогідні зв'язки між попередньо запропонованими та самовизначеними чинниками, зокрема між наявністю попереднього досвіду навчання на кафедрі та зацікавленості в сучасному обладнанні, кількості отриманих балів БПР і тривалості навчання; необхідністю поїздки в інше місто та кількістю отриманих балів БПР і відсутністю комерційної складової. Також аналіз продемонстрував належність чинника зручного оформлення матеріалів до сфери фактора ефективності навчального циклу.

Нові чинники доповнюють ефективність запропонованої авторами чотирифакторної моделі, що передбачає орієнтацію на результат чи на процес, як основну мотиваційну детермінанту вибору форми БПР. Виявлені чинники мають враховуватися під час підготовки інформаційних матеріалів про навчальні цикли.
\end{abstract}

Ключові слова: безперервний професійний розвиток; освітні послуги; післядипломна освіта; мотивація.

Abstract. Transformations of the system of higher and postgraduate education in Ukraine encourage educational institutions to update their approaches to promoting their educational product. Previous studies have investigated targets for the duration and format of training, given an overall assessment of the importance of factors in choosing the form of CME; have identified features of users, who are ready and are not ready to pay for training independently, and key factors in choosing the form of CME. Also, the segmentation of users was carried out. In a new phase of the study, physicians were asked to evaluate additional factors that influence the choice of form of CME.

New factors of the choice of the educational cycle are determined: modern subjects of the course (14.2\% of respondents), the possibility of improving practical skills (8.6 \%), duration of training (4.1\%), convenient design of materials (4.1\%), etc. Statistically significant relationships have been established between previously proposed and self-determined factors, in particular between the

() Ю. В. Вороненко, О. П. Гульчій, К. В. Балашов та ін. 
presence of previous experience of studying at the department and interest in modern equipment, the number of CME points obtained and the duration of training; the need to travel to another city and the number of CME points obtained and the absence of promotion of medicines or services. The analysis also showed that the factor of convenient design of materials belongs to the sphere of the factor of efficiency of the educational cycle.

The new factors complement the validity of the four-factor model proposed by the authors, which provides a focus on the result or process, as the main motivating determinant of the choice of the form of CME. The identified factors should be taken into account during the preparation of information materials about training cycles.

Key words: continuous professional development; educational services; postgraduate education; motivation.

Вступ. Трансформації системи вищої та післядипломної освіти в Україні спонукають навчальні заклади, зокрема медичні, оновлювати підходи до просування свого освітнього продукту та переглядати його зміст $[1,9]$. Завдяки збільшенню доступності IT-технологій дистанційне навчання все більше проникає в освіту дорослих, а комунікація зі споживачами мігрує в інтернет-простір [2, 5]. Визнаним підходом до налагодження комунікації з великими популяціями є сегментація, зокрема з використанням статистичних методів [10].

3 метою вивчення потреб України у сфері безперервного професійного розвитку (БПР) у 2018 р. було розпочате маркетингове дослідження. За його результатами були встановлені цільові показники тривалості і формату навчання, дана загальна оцінка важливості чинників вибору форми БПР [9]; встановлені особливості груп користувачів, готових та не готових оплачувати навчання самостійно [3]; визначені чотири ключові фактори вибору форми БПР (ефективність і доступність циклу, соціальність та формалізм слухача) і сім груп слухачів за цими факторами [4].

На новому етапі дослідження, який проводився 2020 р., лікарям було запропоновано оцінити додаткові чинники, які впливають на вибір форми безперервного професійного розвитку. У результаті на додачу до попередньо запропонованих респондентам чинників (надалі - Ч.) був виокремлений ще 41 запропонований слухачами чинник (надалі СЧ.) [6].

Мета дослідження - поглибити уявлення про чинники та фактори мотивації слухачів стосовно вибору форми БПР й обгрунтувати рекомендації щодо інформаційної складової промоції безперервної освіти.

Методи дослідження. Проаналізовані дані 339 анкет респондентів. Лікарів просили оцінити важливість 15-ти різних чинників вибору форми БПР (вартість циклу, наявність матеріалів для дистанційного навчання тощо - аналізувалися у попередніх статтях). Після відповіді на ці питання респонденти за бажання могли написати інші важливі для них чинники вибору форми БПР (відкрите питання). Відповіді на відкрите питання були опрацьовані відповідно до стандартних підходів: двоє незалежних експертів сформували та узгодили перелік чинників, після чого два експерти закодували відповіді респондентів згідно з отриманим каталогом чинників.

3 метою забезпечення надійності до подальшого аналізу були обрані чинники, які містили 5 або більше відповідей. Визначені показники описової статистики (поширеність, середнє). Статистична вірогідність отриманих різниць перевірялася за допомогою критерію Манна - Уітні (для шкал Лікерта) та t-критерію Стьюдента (для величин, що мали нормальний розподіл). Відповіді респондентів проаналізовано за допомогою пакета SPSS v. 23.

Результати дослідження. Серед 15-ти попередньо запропонованих для оцінки чинників БПР найбільшими балами оцінені наявність матеріалів для дистанційного навчання (медіана 10 б.), вартість циклу (медіана 9 б.) та можливість підтримки діалогу з кафедрою після завершення циклу (медіана 9 б.), а найменшими - рекомендації друзів/колег (медіана 7 б.), наявність серед лекторів професорів (медіана 7 б.) та лекторів - публічних осіб (медіана 5 б.). Ці результати збігаються з показниками попереднього етапу дослідження [3].

Серед самовизначених чинників (табл. 1) найчастіше респонденти називали сучасність тематики курсу (СЧ. 3.5, 14,2 \% опитаних), можливість удосконалення практичних навичок (СЧ. 3.6, 8,6 \%), тривалість навчання (СЧ. 3.2, 4,1 \%) та зручне оформлення матеріалів (СЧ. 3.12, 4,1 \%).

Встановлені статистично вірогідні відмінності в оцінці важливості чинників БПР залежно від обраних ними самовизначених чинників. Слухачі, які вищими балами оцінили важливість попереднього досвіду навчання на кафедрі (Ч. 1), також зацікавлені в сучасному обладнанні (СЧ. 4.1; тут і 
МАТЕРІАЛИ ХИІІІ ВСЕУКРАЇНСЬКОЇ НАУКОВО-ПРАКТИЧНОЇ КОНФЕРЕНЦІЇ 3 МІЖНАРОДНОЮ УЧАСТЮ «АКТУАЛЬНІ ПИТАННЯ ВИЩОЇ МЕДИЧНОЇ (ФАРМАЦЕВТИЧНОЇ) ОСВІТИ: ВИКЛИКИ СЬОГОДЕННЯ ТА ПЕРСПЕКТИВИ ЇХ ВИРІШЕННЯ»

Таблиця 1. Рівні підтримки чинників мотивації слухачів

\begin{tabular}{|c|l|c|}
\hline № 3/п & \multicolumn{1}{|c|}{ Назва } & Рівень підтримки, \% \\
\hline 1 & СЧ. 3.5. Сучасна тематика курсу & 14,2 \\
\hline 2 & СЧ. 3.6. Можливість удосконалення практичних навичок & 8,6 \\
\hline 3 & СЧ. 3.2. Тривалість навчального курсу & 4,1 \\
\hline 4 & СЧ. 3.12. Зручне оформлення матеріалів & 4,1 \\
\hline 5 & СЧ. 3.3. Гнучкий графік навчання & 3,8 \\
\hline 6 & СЧ. 3.4. Наявність дистанційного компонента в навчальному курсі & 3,8 \\
\hline 7 & СЧ. 3.10. Врахування міжнародного досвіду та стандартів & 3,8 \\
\hline 8 & СЧ. 2.3. Професійність & 3,5 \\
\hline 9 & СЧ. 1.2. Кількість отриманих балів БПР & 2,9 \\
\hline 10 & СЧ. 4.1. Наявність сучасного лікувального та діагностичного обладнання & 2,7 \\
\hline 11 & СЧ. 1.7. Територіальна та транспортна зручність & 2,1 \\
\hline 12 & СЧ. 3.11. Можливість користуватися матеріалами після завершення курсу & 1,8 \\
\hline 13 & СЧ. 3.13. Відсутність комерційної складової (реклами препаратів тощо) & 1,8 \\
\hline
\end{tabular}

далі порівнюються групи осіб, які підтримали (П) та не підтримали (Н) відповідний СЧ.: П - 8,6 б., $\mathrm{H}$ - 6,0 б., p=0,010), але менше уваги приділяють кількості отриманих балів (СЧ. 1.2, П - 3,7 б., Н 6,4 б., $\mathrm{p}=0,011$ ) і тривалості навчання (СЧ. 3.2, П 4,7 б., $\mathrm{H}-6,4$ б., $\mathrm{p}=0,038)$.

Висока оцінка територіальної зручності (Ч. 3) позитивно пов' язана з такими чинниками доступності, як кількість отриманих балів (СЧ. 1.2, П - 9,1 б., H - 7,6 б., $\mathrm{p}=0,044)$, територіальна та транспортна зручність (СЧ. 1.7, П - 9,6 б., Н - 7,6 б., р=0,040) i наявність дистанційного компонента в навчальному курсі (СЧ. 3.4, П - 9,3 б., Н - 7,5 б., p=0,011), проте ці респонденти вважають менш важливою відсутність комерційної складової (СЧ. 3.13, П 6,2 б., $\mathrm{H} \mathrm{-} \mathrm{7,8} \mathrm{б.,} \mathrm{p}=0,034)$.

Лікарі, які вищими балами оцінили власну завантаженість (Ч. 6), відзначили важливість сучасної тематики курсу (СЧ. 3.5, П - 8,2 б., Н - 7,5 б., $\mathrm{p}=0,034)$, його практичної орієнтованості (СЧ. 3.6, П - 8,6 б., Н - 7,5 б., p=0,005) і наявності сучасного лікувального та діагностичного обладнання (СЧ. 4.1, П - 9,3 б., Н - 7,7 б., р=0,014).

Респонденти, для яких важливішою виявилася необхідність поїздки в інше місто (Ч. 7), орієнтовані на кількість отриманих балів БПР (СЧ. 1.2, П - 9,3 б., Н - 7,7 б., p=0,025) від проходження навчання та вважають менш важливою відсутність комерційної складової (СЧ. 3.13, П - 6,0 б., Н 7,9 б., $\mathrm{p}=0,032)$.

Подальший аналіз продемонстрував наявність асоціації між чинником зручного оформлення матеріалів (СЧ. 3.12) та важливістю матеріалів для дистанційного навчання (Ч. 12, П - 9,9 б., Н - 9,0 б., $\mathrm{p}=0,022$ ), роботи з пацієнтами (Ч. 13, П - 9,1 б., Н
- 7,3 б., p=0,005). А увага до відсутності комерційної складової (СЧ. 3.13) пов’язана з меншою чутливістю до умов проживання в гуртожитку (Ч. 8, П - 5,5 б., Н - 7,7 б., $\mathrm{p}=0,038)$ та вартості циклу (Ч. 9, П - 7,2 б., Н - 8,4 б., $\mathrm{p}=0,041$ ).

Лікарі, які назвали наявність сучасного лікувального та діагностичного обладнання (СЧ. 4.1) фактором вибору навчального циклу, також більш схильні зважати на наявність попереднього досвіду навчання на цій кафедрі (Ч. 1, П - 8,6 б., Н - 6,0 б., $\mathrm{p}=0,010)$, наявність серед лекторів професорів (Ч. 14, П - 8,1 б., Н - 5,9 б., $\mathrm{p}=0,038$ ) та публічних осіб (Ч. 15, П - 8,0 б., Н - 4,3 б., p=0,001).

Дані почасти доповнюють наявну гіпотезу щодо двох провідних мотивацій для здійснення БПР: здобуття нових компетенцій (орієнтація на результат; ключовим є фактор ефективності навчання) та виконання вимог законодавства (орієнтація на процес; ключовим є фактор доступності навчання) (рис. 1). Про це свідчить спільне спрямування чинників отримання балів БПР, територіальної зручності та необхідність поїздки в інше місто на противагу наявності попереднього досвіду навчання та подальшому спілкуванню з кафедрою, відгукам, наявності міжнародних лекторів та роботі з пацієнтами.

Водночас зайнятість асоціюється 3 більшою потребою в актуальності та практичній орієнтованості циклу, а потреба у відсутності реклами під час навчання - 3 нижчою важливістю чинників доступності.

Розуміння основних мотиваційних чинників важливе також для забезпечення високої якості навчання. Згідно з сучасними дослідженнями, діалог та звернення до власного досвіду слухача, розуміння 


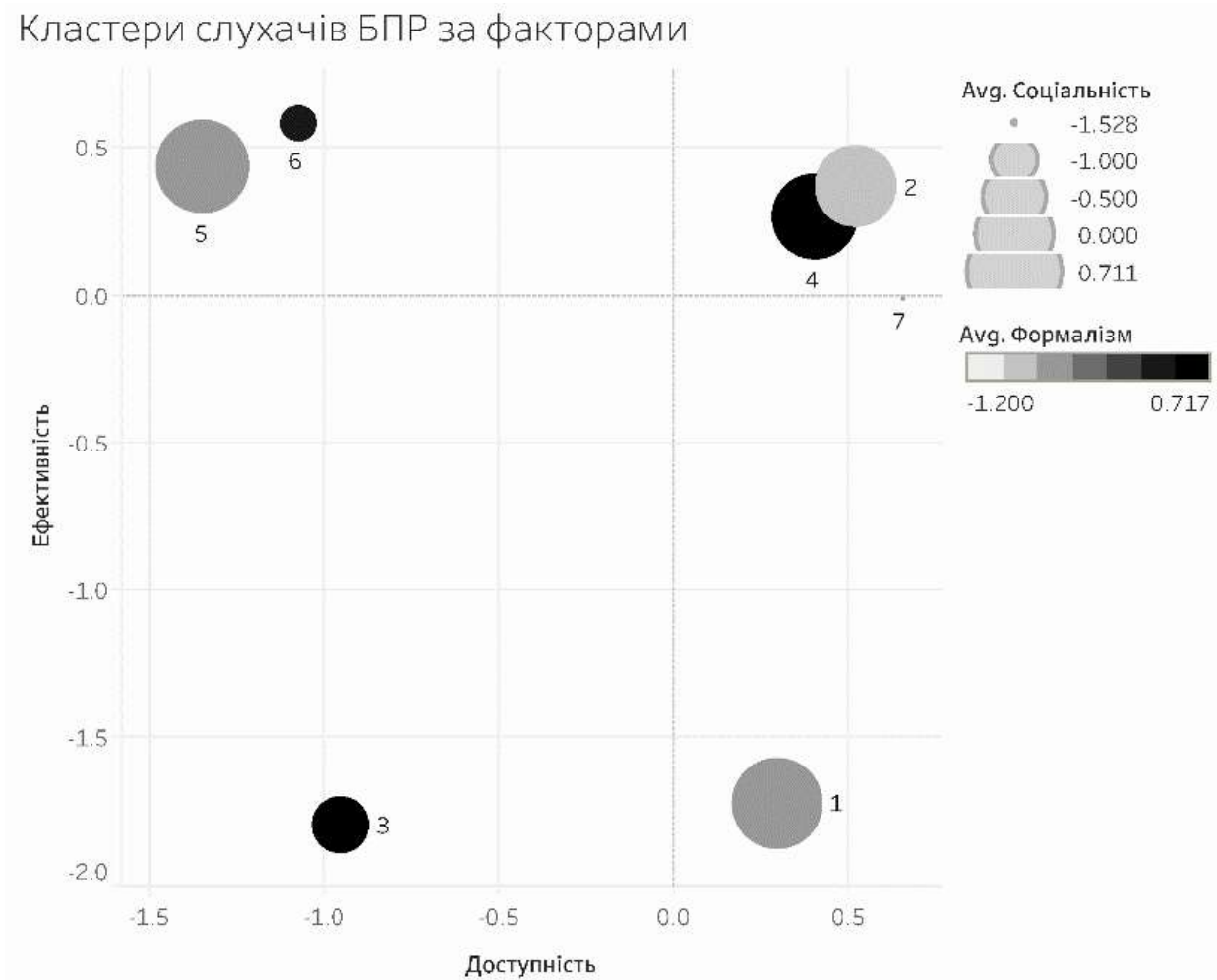

Рис. 1. Групи (кластери) споживачів послуг БПР за ставленням до чотирьох факторів вибору навчального циклу [4].

мотиваційних детермінант здобуття освіти підвищують ефективність навчального процесу [8].

Отримані результати дослідження розширюють розуміння фактора формалізму. Прихильність до наявності сучасного обладнання на противагу тривалості курсу та кількості балів дає можливість припустити, що цей фактор описує швидше консерватизм, довіру до добре перевіреного, ніж виключно орієнтованість на формальні ознаки.

Новацією цього етапу дослідження є демонстрація зручності оформлення навчальних матеріалів як чинника ефективності, що потребує врахування у діяльності кафедр та відображення в інформуванні про проведення навчального курсу.

Пандемія COVID-19 прискорила опанування кафедрами технологій дистанційного навчання та напрацювання власного досвіду підготовки навчальних матеріалів для такої форми [7]. Важливим завданням залишається пошук оптимальних форм поєднання доступності навчального курсу для слухача та забезпечення високої ефективності передачі знань.

Висновки та перспективи подальших досліджень. 1. Аналіз відкритих відповідей респонден- тів щодо чинників впливу на вибір навчального курсу дозволив виявити низку нових важливих для лікарів ознак, які не були внесені до першої версії опитувальника. Серед них актуальність тематики та практична орієнтованість курсу, кількість отриманих балів БПР, гнучкий графік навчання, відсутність реклами під час навчання тощо.

2. Нові чинники в цілому підтверджують ефективність запропонованої авторами чотирифакторної моделі, що передбачає орієнтацію на результат чи на процес, як основну мотиваційну детермінанту.

3. Доцільним $є$ проведення наступного етапу дослідження за новим доповненим опитувальником, що дозволить уточнити фактори та виокремити найбільш показові чинники формування професійної траєкторії розвитку лікарів.

4. Дані щодо важливості зручного оформлення навчальних матеріалів, відсутності комерційної складової, наявності сучасного обладнання необхідно враховувати у роботі та під час підготовки інформаційних матеріалів про цикл, зокрема внести до описів навчальних курсів (курикулумів). 


\section{Список літератури}

1. Вороненко Ю. Організація безперервного професійного розвитку викладачів у системі медичної діяльності (аналітичний огляд та пропозиції) / Ю. Вороненко, О. Мінцер, В. Краснов // Медична освіта. - 2012. № 4. - С. 6-17.

2. Гульчій О. Методологічні аспекти розробки навчальних проектів для післядипломної освіти в охороні здоров’я / О. Гульчій, Н. Захарова // Науковий вісник Національного медичного університету імені О. О. Богомольця. - 2010. - № 1. - С. 197-201.

3. Доказово побудована комунікація: необхідна передумова управління безперервним професійним розвитком / Ю. Вороненко, О. Гульчій, Н. Харченко [та ін.] // Український медичний часопис. - 2020. - № 4 (138), т. 2.

4. Застосування психографічної сегментації для налагодження комунікації у сфері підготовки лікарів / Ю. Вороненко, О. Гульчій, Н. Захарова, К. Балашов // Вісник соціальної гігієни та організації охорони здоров’я України. - 2020. - № 4. - С. 68-75.

5. Комунікаційна компетенція як складова комплексного навчання фахівців громадського здоров’я / Ю. Вороненко, О. Гульчій, Н. Захарова [та ін.] // Україна. Здоров’я нації. - 2017. - № 3 (44). - С. 309-310.

6. Мотивація лікарів до безперервного професійного розвитку: від чинників до концептуалізації / Ю. Вороненко, О. Гульчій, Н. Захарова, К. Балашов // Безперерв-

\section{References}

1. Voronenko, Y., Mintser, O., \& Krasnov, V. (2012). Orhanizatsiia bezperervnoho profesiinoho rozvytku vykladachiv u systemi medychnoi osvity (analitychnyi ohliad ta propozytsii) [Organization of continuous professional development of teachers in the system of medical activity (analytical oliad and proposals)]. Medychna osvita - Medical Education, 4, 6-17 [in Ukrainian].

2. Hulchiy, O., \& Zakharova, N. (2010). Metodolohichni aspekty rozrobky navchalnykh prohram dlia pisliadyplomnoi osvity $\mathrm{v}$ okhoroni zdorovia [Methodological aspects of development of educational projects for postgraduate education in health care]. Naukovyi visnyk Natsionalnoho medychnoho universytetu imeni O.O. Bohomoltsia - Scientific Bulletin of the O. Bohomolets National Medical University, 1, 197-201 [in Ukrainian].

3. Voronenko, Yu., Hulchiy, O., Harchenko, N., Zaharova, N., \& Balashov, K. (2020). Dokazovo pobudovana komunikaciya: neobhidna peredumova upravlinnya bezperervnim profesijnim rozvitkom [Evidence-based communication: a necessary prerequisite for the management of continuous professional development]. Ukrainskyi medychnyi chasopys - Ukrainian Medical Journal, 4 [in Ukrainian].

4. Voronenko, Y.V., Hulchiy, O.P., Zakharova, N.M., \& Balashov, K.V. (2021). Zastosuvannya psykhohrafichnoyi sehmentatsiyi dlya nalahodzhennya komunikatsiyi u sferi pidhotovky likariv [Application of psychographic segmen- ний професійний розвиток лікарів та провізорів в умовах реформування системи охорони здоров'я / МОЗ України, Національна медична академія післядипломної освіти імені П. Л. Шупика. - К. : НМАПО імені П. Л. Шупика, 2020. - С. 140-143.

7. Особливості дистанційного навчання в рамках післядипломної підготовки лікарів з медицини невідкладних станів / А. О. Волосовець, Б. І. Слонецький, І. С. Зозуля [та ін.] // Медична освіта. - 2020. - № 3. - С. 5-8.

8. Хижняк М. В. Стилі навчання дорослих за моделлю Колба: можливості освіти, психологічних змін та трансформації життя / М. В. Хижняк // Андрагогічні засади освіти дорослих: теорія й інноваційна практика : матеріали методологічного семінару / за заг. ред. О. Є. Гречаник, Т. М. Хлебнікової. - Х. : ТОВ «Планетапрінт», 2018. - С. 94-103.

9. Methods for communication processes enhancement in the "Provider-Consumer (Learner)" system of educational services / Y. Voronenko, O. Hulchiy, I. Khomenko [et al.] // Wiadomości Lekarskie. - 2020. - T. 73 (8). - S. 1663-1667.

10. Slater M. Choosing audience segmentation strategies and methods for health communication / M. Slater // Designing health messages: approaches from communication theory and public health practice / E. Maibach, R. L. Parrott, eds. - Thousand Oaks, CA : SAGE Publications, 1995. P. 199-200.

tation for communication in the field of doctor training]. Visnyk sotsialnoyi hihiyeny ta orhanizatsiyi okhorony zdorovya Ukrayiny - Bulletin of Social Hygiene and Health Care Organization of Ukraine, 4, 68-75 [in Ukrainian].

5. Voronenko, Y., Hulchiy, O., Zakharova, N., Khomenko, I., Balashov, K., Turianytsia, S., \& Iork, E. (2017). Komunikatsiyna kompetentsiya yak skladova kompleksnoho navchannya fakhivtsiv hromadskoho zdorovya [Communication competence as a component of comprehensive training of public health professionals]. Ukrayina. Zdorovya natsiyi - Ukraine. Health of the Nation, 3(44), 309-310 [in Ukrainian].

6. Voronenko, Yu., Hulchiy, O., Zaharova, N., \& Balashov, K. (2020). Motyvatsiya likariv do bezperervnoho profesiynoho rozvytku: vid chynnykiv do kontseptualizatsiyi [Motivation of doctors for continuous professional development: from factors to conceptualization]. MOZ Ukrayiny, Natsionalna medychna akademiya pislyadyplomnoyi osvity imeni P. L. Shupyka. Bezperervnyy profesiynyy rozvytok likariv ta provizoriv $v$ umovakh reformuvannya systemy okhorony zdorovya - Continuing professional development of doctors and pharmacists in the context of health care reform. Kyiv: P. L. Shupyk NMAPO [in Ukrainian].

7. Volosovets, A.O., Slonetskyy, B.I., Zozulya, I.S., Bobrova, V.I., Ivashchenko, O.V., Verbytskyy, I.V., \& Savchenko, D.S. (2020). Osoblyvosti dystantsiynoho navchannya v 
ramkakh pislyadyplomnoyi pidhotovky likariv z medytsyny nevidkladnykh staniv [Features of distance learning in the framework of postgraduate training of doctors in emergency medicine]. Medychna osvita - Medical Education, 3, 5-8 [in Ukrainian].

8. Hizhnyak, M.V. Ctyli navchannya doroslykh za modellyu Kolba: mozhlyvosti osvity, psykholohichnykh zmin ta transformatsiyi zhyttya [Adult learning styles according to the Kolb model: opportunities for education, psychological changes and life transformation]. O.Ye. Hrechanyk, T.M. Khliebnikova. Andrahohichni zasady osvity doroslyh: teoria y innovatsiyna praktyka materialy metodolohichnoho seminaru - Andragogical principles of adult education: theory and innovative practice: materials of the methodological seminar. Kh: TOV «Planeta-print» [in Ukrainian].

9. Voronenko, Y., Hulchiy, O., Khomenko, I., Zakharova, N., \& Balashov, K. (2020). Methods for communication processes enhancement in the "Provider-Consumer (Learner)" system of educational services. Wiadomości Lekarskie, 73 (8), 1663-1667.

10. Slater, M. (1995). Choosing audience segmentation strategies and methods for health communication. E. Maibach, R. L. Parrott (Eds.). Designing health messages: approaches from communication theory and public health practice. Thousand Oaks,CA: SAGE Publications.

Електронна адреса для листування: mollyyula@gmail.com 